\title{
A translation of the Linnaean dissertation The Invisible World
}

\author{
JANIS ANTONOVICS $^{1}$ and JACOBUS KRITZINGER ${ }^{2}$ \\ ${ }^{1}$ Biology Department, Gilmer Hall, McCormick Road, University of Virginia, Charlottesville, VA 22904, USA. \\ Email: ja8n@virginia.edu. \\ ${ }^{2}$ Department of Ancient Languages and Cultures, University of Pretoria, Lynnwood Road, Hatfield, Republic of \\ South Africa.
}

\begin{abstract}
This study presents the first translation from Latin to English of the Linnaean dissertation Mundus invisibilis or The Invisible World, submitted by Johannes Roos in 1769. The dissertation highlights Linnaeus's conviction that infectious diseases could be transmitted by living organisms, too small to be seen. Biographies of Linnaeus often fail to mention that Linnaeus was correct in ascribing the cause of diseases such as measles, smallpox and syphilis to living organisms. The dissertation itself reviews the work of many microscopists, especially on zoophytes and insects, marvelling at the many unexpected discoveries. It then discusses and quotes at length the observations of Münchhausen suggesting that spores from fungi causing plant diseases germinate to produce animalcules, an observation that Linnaeus claimed to have confirmed. The dissertation then draws parallels between these findings and the contagiousness of many human diseases, and urges further studies of this 'invisible world' since, as Roos avers, microscopic organisms may cause more destruction than occurs in all wars.
\end{abstract}

\section{Introduction}

Here we present the first translation from Latin to English of the Linnaean dissertation published in 1767 by Johannes Roos (1745-1828) entitled Dissertatio academica mundum invisibilem, breviter delineatura and republished by Carl Linnaeus (1707-1778) several years later in the Amoenitates academicae under the title Mundus invisibilis or The Invisible World.

${ }^{1}$ Roos was a student of Linnaeus, and the dissertation is important in highlighting Linnaeus's conviction that infectious diseases could be transmitted by living organisms. Although pointed out long ago by Hjelt, and several other authors since, it is generally not appreciated that Linnaeus argued that many contagious diseases could be caused by living organisms, often too small to be seen. ${ }^{2}$ Biographies of Linnaeus often fail to mention these important contributions even when they pertain directly to his work as a physician. ${ }^{3}$ We now know that Linnaeus was correct in ascribing the cause of diseases such as measles, smallpox and syphilis to living organisms. Although historians tend to condemn 'what-if' analyses, one could not be blamed for wondering how many lives might have been saved if Linnaeus's ideas had had the same traction as those of Louis Pasteur (1822-1895), almost a hundred years later. ${ }^{4}$

Linnaeus oversaw 186 theses written and defended by his students either for intermediatelevel degrees or for their medical degrees. ${ }^{5}$ The status of these theses has been extensively discussed, and the general consensus is that they were often elaborations, or even transcriptions, of lectures given by Linnaeus himself. ${ }^{6}$ Indeed Linnaeus published them as 
chapters in seven volumes under the title Amoenitates academicae, often with his own amendments and alongside other short texts, like academic speeches, with a further two volumes being produced posthumously.

Literally translated, Amoenitates academicae would be Academic Pleasures, but perhaps Academic Reviews is a more appropriate modern interpretation. Because these dissertations reflect Linnaeus's own opinions and thought processes, they have a special place in the history of biology. The dissertations cover the state of knowledge at that time across a large number of topics in biology and medicine, and go well beyond the better-known contributions of Linnaeus to plant and animal classification. However, fewer than 10 per cent of these theses have been translated into English. Indeed, since the early translations by Brand and by Stillingfleet, ${ }^{7}$ we know of only two that have been translated into English subsequently, namely Living Rashes and Fundamentals of Ornithology. ${ }^{8}$

Living Rashes or Exanthemata viva was published in 1757, several years before Mundus invisibilis, as Johannes Nyander's (1734-1814) dissertation. It also ascribes contagion to living organisms and has been thoroughly analysed by DeLacy and Cain. ${ }^{9}$ This and the dissertation translated here stand rather alone, since neither Roos nor Nyander followed academic careers, nor did they otherwise elaborate on the issues of contagion. Nyander became a practising physician, graduating from Greifswald in 1760, but published no other text. ${ }^{10}$ Roos's dissertation was for an intermediate degree (dissertatio academica pro exercitio), and his subsequent medical dissertation (dissertatio medica) was under Jonas Sidrén (1723-1799), and on lumbago, not on contagious diseases. ${ }^{11}$ Roos then became a physician to the poor. ${ }^{12}$ Sidrén had himself been a student of Linnaeus, and moved to the professorship of anatomy and medicine, like his teacher, in Uppsala. ${ }^{13}$ He supervised a large number of dissertations on medical subjects, including cholera and exanthematas, but we know of no analysis of Sidrén's contributions to medicine or of his relationship with Linnaeus. ${ }^{14}$

As suggested by DeLacy and Cain, Linnaeus seems to have treated these dissertations on contagious diseases more like 'trial balloons' rather than as something to be pursued and elaborated, since he too did not continue this work in any substantive way. ${ }^{15}$ His students subsequently produced well over thirty theses, but these were mostly on the medicinal properties of plants. It was about this time that Linnaeus was focused on his next 'magnum opus', the Clavis medicinae duplex, in which he attempted to classify diseases coordinately with their smells and tastes and corresponding therapies. ${ }^{16}$ It was this project and the more general issue of dietetics that were foremost on Linnaeus's mind, as evidenced from the extensive annotations to the first edition of Clavis medicinae. ${ }^{17}$ Although never stated explicitly in his writings, it was as if Linnaeus's ideas on contagion remained a tantalizing conjecture; presumably he could see no direct way in which to attack or interrupt a world which was mostly invisible.

\section{Synopsis}

The dissertation is divided into two chapters; the first chapter is 'about Well Known things, but recently discovered', and the second 'about More Obscure things, in order to encourage [future generations] to apply their minds to it'. The dissertation first describes how Linnaeus, using a microscope, showed Roos that the 'seeds of Ustilago' (the germinating spores of the smut fungi) were 'moving and racing about like fish'. Roos then goes on to say that this made him realize that 'small things are no less worthy of observation, or admiration, or less 
necessary than are the larger things', and that through 'armed eyes' (i.e. helped by the microscope) 'I have seen the greatest miracles of the very powerful Creator who made nothing in vain and who created nothing without a purpose and use'.

The first chapter reviews recent discoveries by leading microscopists, especially the works of Dillen on mosses, Trembley on Hydra, Réaumur on insects, and Ellis on corals and bryozoans. ${ }^{18}$ Organisms which before were just 'mucoid spots' are now seen to be complex animalcules, with remarkable properties. They regenerate when split into smaller pieces, and they recover from desiccation. Roos wonders, 'Who would believe it, unless he had seen it?' Previous authors had believed corals were rock, then 'living flowers', until further studies by Ellis showed that the flowers were animals in the form of polyps. A controversy raged about whether these were plants or animals, 'until my Lord President settled the matter in Systema Naturae 10th edition, that indeed these were Zoophytes'. ${ }^{19}$ Roos compares the colonial nature of zoophytes with grasses that root from small pieces, and with the segmental nature of the tapeworm. ${ }^{20}$ The stalk that supports the polyps of zoophytes is considered to be part of the whole organism, in the same way that the shell of a mollusc is produced by the animal and therefore part of it. Roos then turns to 'INSECTS, which common people greatly despise ... even though they are the works of the very wise Creator who clearly created nothing without purpose'. He considers them to be Nature's police, keeping the numbers of other organisms in check. ${ }^{21}$ As a result of microscopes, 'fifty times more insects have been discovered during our age than in the whole period before us'. Microscopes have also given insights into plants, as when Guettard showed that 'the simple surface of the plants was so skilfully formed ... that it seemed as if complete forests ... were depicted on single leaves'. This chapter is forceful and direct, typified by the statement that if large animals had been seen on land, attached to trees like polyps, who 'would not have undertaken long journeys, and at great speed, in order to go and look at this phenomenon'?

The second chapter, 'about More Obscure things', begins abruptly by comparing the discoveries of magnetism, electricity and the regeneration of the polyps with the discoveries of Baron Otto von Münchhausen which 'will give much light and illumination to the curious'. ${ }^{22}$ One hears the voice of Linnaeus when microscopists are chastised for only observing things under the microscope and not daring 'to insert them into the system of animals', a clear allusion to his creation of the class Chaos in the 12th edition of the Systema naturae. Roos then quotes extensively from Münchhausen's book Der Hausvater which had just appeared the year before, and which claimed that the black flour of fungi (i.e. their spores) are really the eggs of animals; and that 'these seeds, when put in tepid water for some days, germinate into real little worms, clearly visible with microscopes, and at length weave a small web, to which they stick firmly and grow into the Fungi to which they owe their origin'. Strong praise follows: 'We indeed regard this discovery as so great that if no other monuments of this most noble Man existed, this alone would still furnish immortal glory to this most illustrious author'. Two extracts from Der Hausvater are included (translated into Latin from German), with their account of the production of 'animalcules' from fungal spores and practical remedies for controlling disease by washing the seeds free of the dust: 'Truly this is contagion in the plant kingdom'.

This is followed by an account of the same observations by Linnaeus: 'We have seen this experiment repeated by our Lord the president'. ${ }^{23}$ Unfortunately, the observations are difficult to interpret. Few details are given. For example, the 'black dust' refers to fungal spores, but we are not told whether it came from wheat, barley or some other source. The dust was immersed in water and 'exposed to summer heat for a few days', but it is not clear what 
this time period was. Some 'dust', like the spores of the loose smut of barley, can germinate in a day or two, whereas the stinking smuts or bunts would take longer. ${ }^{24}$ 'Animalcules' being driven from the eggs might represent the initial production of a fungal germ tube, but there are no illustrations. Their shape and movement ('oblong, fairly blunt more to the front, swimming like playing fish, sometimes with a jump') suggests a ciliated protozoan, such as Paramecium. But there are no details of the lens that was used nor of its magnification. ${ }^{25}$ The transformation of these animalcules back into fungi is then described, 'After a period of a few days, it seemed as if some were beginning to build a web [perhaps hyphae] ... like mucor'. The interpretation of these observations is vindicated by the results of Münchhausen: 'These kinds of things would have been obscured by much darkness if that most Famous Münchhausen had not made such good progress with his experiments'.

These findings are then extrapolated directly to humans: 'This argument will also lead doctors to the cause of exanthematic and contagious fevers ... He who has considered that only one small part of ustilago flour is multiplied through all the ears of that same Wheat or Barley plant will find a considerable analogy'. Roos calls for more studies: 'At least someone with an inquisitive nature, suffering from Syphilis or gonorrhoea, should have, through experiments, searched in his foul dripping seed to see whether and what kind of animalcules it contains'. The dust clouds seen in the air in the summer sunlight by Réaumur are also suspected to house animalcules and it is suggested that these may come from mucor-like particles in the air.

The last paragraph refutes the concept of spontaneous generation, and suggests that 'we must certainly speculate and investigate whether diseases, for example intermittent and exacerbating fevers ... owe their origin to infinitely small animalcules'. The ending is poetic, and prescient: 'Hence the smallest animals perhaps cause greater destruction than the biggest; and they probably destroy even more than all the wars. But I cannot bear to proceed further with my conjectures. Another day and the diligence of a longer lifetime will bring these and more things to light'.

The thesis ends with a page titled 'Scholia' or critical questions for further discussion. One of these Scholia, 'Are Animalcula infusoria disseminated out of the Seeds of Mould?', was inserted into the Amoenitates version certainly by Linnaeus himself as it is not in the original Roos dissertation. Between the publication of the dissertation and its incorporation into the Amoenitates, Linnaeus had come to doubt his observations because they could not be confirmed by John Ellis, the English microscopist with whom he had corresponded. ${ }^{26}$

\section{Translator's notes}

The translation is based on C. Linnaeus, Mundus invisibilis, in J.C.D. Schreiber (ed.), Amoenitates academicae seu dissertationes variae physicae, medicae botanicae antehac seorsim editae nunc collectae et auctae cum tabulis aeneis, vol. 7, 2nd edn, Erlangen: J.J. Palm, 1789, pp. 385-408. The first edition had an identical title, but was published in 1769 in Stockholm by L. Salvius. The text and pagination are identical in both editions. The page numbers in the translation are as in these editions.

We have indicated in the footnotes whenever the Amoenitates version differs substantively from the original dissertation, but we have not noted minor changes in spelling or punctuation. An examination of Linnaeus's own copy of Roos's dissertation at the Linnean Society of London revealed no annotations. 
We have tried to keep the translation as literal as possible, and avoid placing our own interpretation on the words. Ambiguity and uncertainty of meaning are addressed in the footnotes. Footnotes present in the original version are included in the text to distinguish them from our own notes. Capitalization (upper-case letters) and italics have been kept as in the original text, even though used inconsistently. There is an early Swedish translation of Mundus invisibilis by Fries, ${ }^{27}$ but we have made this translation independently (except for checking a few notes, where indicated). Because we are not Swedish-speakers, we leave it to others better qualified to judge the relative merits of the two translations.

The names of people are translated from the Latin into the language of their native country as often as possible. In the notes, we usually only include their names plus dates of birth and death, and not summary biographies, as these are generally accessible online. The names of organisms have also been translated into English as far as possible; footnotes are added where an organism is not well known, or there is ambiguity about the identification.

Janis Antonovics primarily contributed to the historical and biological context, while Jacobus Krizinger primarily contributed to the translation. A fuller discussion of the issues raised by this dissertation is forthcoming. ${ }^{28}$

\section{The translation}

\section{p. 385 [page numbers as in the Amoenitates text]}

CXLVI $^{29}$

'The invisible world' with D.D. Carl von Linné presiding, which Johannes Carolus Roos of Stockholm presented, Upsala 1767, March 6th.

\section{CHAPTER I}

$\S I$.

Man was created with the intention to contemplate the things created by divine workmanship and to acknowledge its creator, while admiring creation. This was once said by the most learned Ray, ${ }^{30}$ which sharpened my attention to such a great extent, that I wished to examine nature with all my effort. For this natural obligation is very useful in all circumstances, and, through its huge variety of miracles, it is an exceptional delight without which there would be solitude everywhere. Therefore I have collected insects not unwillingly and in these very small animalcules, ${ }^{31}$ I have seen the greatest miracles of the very powerful Creator who made nothing in vain and who created nothing without a purpose and use. Not long ago, when our Noble Lord, the President, ${ }^{32}$ was busy examining the seeds of Ustilago, ${ }^{33}$ he showed me very clearly that these seeds are moving and racing about like fish,

p. 386

that they are indeed living animalcules, which afterwards become silent and immovable bodies (according to a law of nature unheard of until now and which surpasses the total understanding of man, so that many people would say that it could not possibly happen, unless they could see it with their eyes and touch it with their hands). This offered me, who was about to publish my first Academic work, the opportunity to reflect upon the exceptional 
advances of the natural sciences in the present age, through attention to very small natural objects, which the older generation did not regard as important and which are not seen by the general public, but these small things are no less worthy of observation, or admiration, or less necessary than are the larger things. At first, when we came into light, ${ }^{34}$ the biggest and largest animals offered themselves for study, and as a result of this everyone wanted to write his own natural history to describe Horses and Dogs, since these animals are among the first to become known to us. Unlearned people who undertook a journey to the Indies, in their diaries and itineraries, hardly fail to mention the very big Elephants, Rhinoceroses, Camels, Crocodiles, Whales, even tall Palms, Baobabs, Cucumber Trees, Cedars, etc.; ${ }^{35}$ but too seldom do they pay attention to very small Mosses, to Algae, Mites, Hydras, and similar things which deserve no less attention than the bigger animals. Therefore I have decided to rouse the interest of others ${ }^{36}$ in the very small natural bodies which either the common people don't see or don't know that they exist, and I perceive these things just as an INVISIBLE WORLD in the visible one which includes only those small bodies that can be observed with armed eyes or through microscopes. And there will be two headings for this discussion:

1. About Better Known things, but recently discovered.

2. About More Obscure things, to be entrusted to the diligence of men in the future, as above all it is my wish to encourage them to apply their minds to it.

p. 387

$\S I I$.

MICROSCOPES, well known from ancient times until the present, have given us a way of closely examining the smallest bodies that are near to us, just as Telescopes provided Astronomers the opportunity of observing larger celestial bodies existing far away from us. Recently Microscopes have been improved and strengthened so that they can provide more illumination when used. And in this regard Lieberkühn, ${ }^{37}$ not to mention others, acquired immortal fame for himself with his lenses. In past years, Zoology has been investigated by Gesner, Aldrovandi, Willughby, Ray; ${ }^{38}$ botanical science has been studied by L'Obel, Dodoens, L'Ecluse, the Bauhin brothers, Tournefort, Ray and others, ${ }^{39}$ and you would think that, at least in Europe, numerous things in the natural sciences have been discovered and pondered. But this Age has presented us with almost double the amount of miracles of nature than the previous one had seen, because it will be accessible to him who reads about the plants of Plumier, Browne, Jacquin, Burman, Rheede, Rumpf and others; ${ }^{40}$ the birds of Edwards and Brisson; ${ }^{41}$ the insects of Réaumur, Rosenhoff; ${ }^{42}$ the shellfish of Rumpf, Bonannus, Lister, d'Argenville ${ }^{43}$ and the sea fir of Ellis, ${ }^{44}$ not to mention the rest. The Museum of nature stood before me like a palace, having by far the most vaults filled with the Creator's astonishing works of art and miracles, in which individual genera have their own place. The first entrance to the biggest amphitheatres of Nature is accessible to anyone, but the smaller ones are often closed. Skill is necessary to open little by little the door of a specific chamber where a new, as it were, inner world presents itself to the eyes. After the doors of flower- and fruit-bearing plants were opened by Gesner, the Thread of Ariadne ${ }^{45}$ for the whole field of BOTANY was found to be beyond expectation. He who first flung open the door of the chamber of ELECTRICITY through rubbing amber, did not at all think that a whole science, now a delight to all curious people, was locked inside such a room. No one would have believed that a few strange monstrous flowers ${ }^{46}$ could unlock the chamber 
of the PROLEPSIS of plants, ${ }^{47}$ which created a large benefit to posterity, or that the Aconitum would open the chamber to the BREAD OF EUROPE. ${ }^{48}$ However, Microscopes offered a special key to open up the bolts of the Palace which had been closed through all the ages. MOSSES had indeed been investigated by the Englishman, Ray, and his contemporaries, but they weren't studied sufficiently, until Dillen ${ }^{49}$ intentionally undertook to collect, to reveal, to describe, to delineate and to name the Mosses and Lichens, and he alone produced a large array of more than 600 species. But not all of them can be perceived and defined with the naked eye; therefore, microscopes were absolutely necessary for both their description as well as their illustration. With the microscopes they now at last were brought into the open, so that they could be easily and thoroughly examined and their uses could become evident in the art of Dyeing, Medicine, with regard to Food, Bedding, ${ }^{50}$ Buildings, Horticulture, and recently especially in the Economy of Nature, ${ }^{51}$ such that a region would be very unfortunate to be robbed of Mosses. Nowadays, no wise man would dare to say that those who collect mosses and flies ${ }^{52}$ accomplish nothing and are wasting their valuable time, in that they contemplate the wonderful works of the Creator and teach us how to turn them to appropriate use.

\section{\$III.}

Trembley ${ }^{53}$ saw with a microscope an animalcule in the water, resembling a mucous spot, which would be impossible to see with the naked eye; he observed that it extends its tentacles to collect food with them; he saw that these tentacles, after they had been removed with the help of small scissors, grew back; and that this little body itself, when cut apart with scissors, formed two animalcules. This simple experiment in 1739 opened the door of the chamber of POLYPS, ${ }^{54}$ which delighted attentive and interested people with the greatest miracles. While this created much work for the immortal Réaumur, the pride of France, soon after it was discovered, the illustrious botanist Bernh. Jussieu set out for the coast of Normandy and

\section{p. 389}

the brilliant Guettard to the coast of Scotland for this reason. ${ }^{55}$ Baker, Ellis, Baster, Roesel, Ledermüller, Schaeffer ${ }^{56}$ and many others found here a wide open field to which to apply their attention and diligence with microscopes. Many Hydrae, Vorticellae ${ }^{57}$ and other kinds of worms, ${ }^{58}$ which had not been known to anyone before, were discovered. These were found here in almost all water, either invisible to the naked eye or like very small mucoid spots, but with microscopes they were observed to be more often complex animalcules, equipped with branches in the manner of plants, where the single spots represent complete animals. It was observed that they could be split up so that from each simple animal or branch, more animals could be formed and that when a tentacle is removed with a pair of scissors another complete body is immediately formed, so that the separated little arm would grow again into a whole Animal. It seemed that these bodies were enlarged by branches or gemmae, ${ }^{59}$ in the manner of vegetables, and even if divided they fused, so that the half of a dissected body, joined with another one, would grow together into a whole animalcule. One single opening was found in these simple bodies, which simultaneously fulfilled the role of mouth and anus, in such a way that they would return things which had been swallowed and were often bigger than themselves, after the juice had first been extracted, from the same opening through which they had been taken in. But that surpasses all ideas of Physiology, because if a Polyp is twisted and inverted inside out, it nevertheless lives and is nourished as 
before; not to mention that these animalcules dry out in the streams when the water dries up during summertime, and then die but revive again when the rainwater flows in, and they regain their former vitality, just like Mosses which dry out during summer, like dust, but regain activity in autumn and winter. Who would believe it, unless he had seen it? In the meanwhile, this matter is indeed so certain that if someone doubts it, he could himself see all these things through microscopes. I refrain from mentioning Noctilucae marinae, Nereids so small

p. 390

that they escape being seen, but nevertheless are so plentiful that they illuminate the whole ocean at night and make it possible for ships to sail at night as if under the brightest fire; and these animals would perhaps have been unknown to this day if Vianellio had not discovered those microscopes. ${ }^{60}$ Yes indeed, Volvox and Proteus, with their wonderful characteristics, would still have been concealed without the help of microscopes.

$\$ I V$.

Previous authors used to consider the CORALS as a kind of rock, and because they resembled lime, they believed that they came into being in the manner of Diana's tree, ${ }^{61}$ until Colleague Marsigli started to examine Corals from the Mediterranean Sea. ${ }^{62}$ These were (it seemed to him) living flowers, furnished with eight petals, eight stamens and one pistil, but so transitory, that they immediately contracted when lifted into the air, but unfolded again once dipped in water. The enquiring man had no choice but to relate these Corals, thus described and outlined, to the plants of the world, and indeed when Peyssonnel, ${ }^{63}$ a Doctor from Marseilles, told Réaumur in the following year that corallia were formed by animals, he could not persuade anyone of such a strange matter and perhaps the miracle would still have remained hidden, if Trembley had not opened up the entrance through the discovery of Polyps. ${ }^{64}$ While everyone was studying Polyps, that very sharp, inquisitive and truly immortal John Ellis ${ }^{65}$ began to examine mosses on the sea floor with microscopes, in the same way that Dillen ${ }^{66}$ had examined his terrestrial mosses, and to describe and delineate them in an incomparable work about Corals. He saw that these showed an animal at the individual protrusions, ${ }^{67}$ similar to an attached flower which is spread out in the form of a Polyp, seizing impure particles from the water with its tentacles and moving them to its mouth; he saw that it contracted when touched, but when left alone, it expanded and moved as before; furthermore when this flower withered,

\section{p. 391}

it finally swelled up into a little capsule, which eventually opened up and dispersed its seeds. Indeed, he who contemplates these things has no choice but to be struck with amazement at the wonderful works of the Greatest Creator. If a thing of that kind had been produced in an organism of larger size and on nearby land, no one, in my opinion, would have been so uninterested that he would not have undertaken long journeys, and at great speed, in order to go and look at this phenomenon. Could you imagine, interested Reader, a tree, which instead of leaves, had flowers or gemmae, and from each of the gemmae a small head of a bird or of some other animal was clinging to a neck which could be extended or drawn in? And imagine that these individual heads are in continuous action chasing insects with their beaks and acquiring food for themselves in this way. Who would not regard it worthwhile to turn his eyes to examine these things? Who could be so foolish that he could disregard these things 
with contempt? But of such a nature are not only all the ZOOPHYTA ${ }^{68}$ which grow like forests on the seafloor; of such a nature are also the Soft Corals, Sea Fans, Tubulariae, Leafy Bryozoans, Corals, Bryozoans and others like them. ${ }^{69}$ And so, when they who had examined the Polyps so accurately saw the polyp-formed flowers, it was indeed very difficult to perceive that not only were Polyps Animals produced by Corals, but also that Polyps were able to establish a body so regularly, such as can be seen in the Venus Sea Fan, the branched Alcyonium, Isis Hippuris and others. ${ }^{70}$ Therefore, it was enough for them to believe that these animated flowers or Polypi were invaders, clinging to Zoophytes so that they could feed on them, just like the larvae of insects on their plants. But this opened the circumstances for a more troublesome controversy, especially discussed between two very diligent men, Ellis and Baster, ${ }^{71}$ until my Lord President settled the matter in Systema Naturae 10th edition, that indeed these were Zoophytes, that the plant was vegetable but the flower animate, ${ }^{72}$ as a result of which the concept of Zoophytes

p. 392

also became clearer.* $\left\{{ }^{*}\right.$ Footnote in the original text: But as far as I know, the Illustrious Linnaeus firstly and rather boldly presented this theory about most Zoophytes in his tenth edition of the Systema Naturae. Influenced by the expressed publications of Linnaeus, the very bright Baster, who until this time had stood in opposition to Ellis and the other advocates of the earlier opinion, gave in to the evidence of the other side and with the most glorious example, he rejected his earlier opinion and started to zealously defend the true Theory. ${ }^{73}$ Pallas Zoophyt. 20.\} But he who wants to understand this, has to form for himself the idea of composite animals from the Tapeworm, ${ }^{74}$ which is a worm of very many segments each of which has all the requirements of life, with a medullary origin, ${ }^{75}$ digestive system, ${ }^{76}$ mouth, etc., in such a way that, if singular segments are torn off, any part would nevertheless constitute its own organism, just as the individual segments will produce individual plants if you cut off the root of Triticum repens. ${ }^{77}$ The Creator has placed the marrow, the seat of life in most of the other animals, inside a bony crust which cannot be extended further once it has hardened into solid bone, but in the case of Worms, where there is no obstacle to the marrow, it multiplies itself into more animals, and the same in the case of plants, where any branch becomes a new plant, or vegetable life which can also be separated and bring forth roots when entrusted to the earth, be grafted onto other trees and be propagated. Here I shall give a word of caution that those people who seemed to have observed the Head at the thicker end of the Tapeworm have made a mistake since anyone could scarcely find a head in any small worm; much less will a head be able to exist on the thinner end, which grows every day with new articulations. ${ }^{78}$ CORALS are especially related to Zoophytes, and the boundaries between them are no less than between the other kingdoms of nature, but in the smallest things that are very difficult to find; and in order to establish these boundaries, Mushroom Corals should be taken into account. ${ }^{79}$ It is an animalcule, produced out of its own egg, and if I'm not mistaken, an annual one; it lays a coralline basis under itself and when it dies, it leaves the corallium behind. ${ }^{80}$

\section{p. 393}

So it is an animal that builds under itself, just as a shellfish builds outside itself, and it cannot be said that the coralline stem is animate in Zoophytes, no more than a shell of Shellfish grows out into the animal that it encloses. If the animal of the Mushroom Corals is indeed compound and sends out branches like a Hydra, then every branch of the animalcule builds its own base, such that the Mushroom Corals become compound. The same applies to the 
Fire Corals ${ }^{81}$ which therefore should not at all be confused with zoophytes. I refrain from mentioning the very small NAUTILUS of the Mediterranean Sea, from the coast of Ariminum, like Calcar, crispus, Beccarii, rugosus, umbilicatus, obliquus, Raphanus, Granum, Radicula, Fascia, Sipunculus, Legumen, which were collected by Beccarius, Plancus and others, which are smaller than Sand and hid themselves from the eyes of men until our times. ${ }^{82}$

$\S \boldsymbol{V}$.

Many things should still be said about the world hidden from the eyes of ordinary people if I would bring myself to contemplate INSECTS which common people greatly despise including older people from whom you would expect better, who think of them as children's playthings and magic tricks, even though they are the works of the very wise Creator who clearly created nothing without purpose. We have seen in our time, after attention was given to these animalcules, that through them an equilibrium is kept in the plant and animal kingdom of nature, in such a way that not any one of these things could just be eliminated without removing the effects of Nature's Police. ${ }^{83}$ For these organisms, more than the very big animals, operate with their huge number compensating for their size, not to mention their wonderful economy, in transformation and other properties. Bees, Silkworms, Ants and Aphids all have exercised the diligence of very clever men. Then, with their eyes now open and the diligence of more people aroused, fifty times more insects have been discovered during our age than in the whole period before us. But microscopes were marvellously useful in this regard

\section{p. 394}

without which Aphis, Chermes, Coccus, Thrips, Podura, Acarus, etc. ${ }^{84}$ could never have been so accurately examined. My Lord the President has a Phalaena occultella ${ }^{85}$ moth so small that it could scarcely equal the extreme top of a hair, ${ }^{86}$ and no one without a microscope would believe that it is a Phalaena, unless it moves. We observe the smallest flowers in the plant kingdom and their STAMENS and PISTILS, which are in very many instances so minute, that they escape the sharpest vision, using armed eyes. ${ }^{87}$ These optical instruments have shown to us the FORM OF THE POLLEN of the anthers, which just like the form of Seeds, differs infinitely, and not so long ago the very interested Guettard examined the covering of plants with his eyes artificially improved and he saw that the simple surface of the plants was so skilfully formed into diverse kinds that it seemed as if complete forests with particular forms were depicted on single leaves.

\section{CHAPTER II}

\section{$\S I$}

The inclination of a Magnet towards the Boreal and arctic Pole, a trifling thing indeed, opens the way for man to both Indies. That rubbed Amber or sealing Wax attracts small pieces of paper has taught man to draw down thunder from the clouds. The Polyp cut with scissors ${ }^{88}$ has shown the way to the knowledge of composite animals and Zoophytes. The chain of nature comes and returns in a circle, and each link leads to another; therefore, one truth laid open by experiments brings about a long series of consequences and affinities. One unclosed door of nature, which was not accessible to anyone up to this point, has shown the greatest number of prodigies. The immortal Baron OTTO MUNCHHAUSEN ${ }^{89}$ has truly opened such 
an entrance for us. Up to now, many stationed at the door with us, with hairs standing on end and with astonished mind, have wished to pry into so many hidden treasures in this chamber: but no

\section{p. 395}

one as far as I know, has dared to enter; but nevertheless this discovery, more accurately pondered, will give much light and illumination to the curious.

\section{$\$ I I$.}

There are several authors called MICROGRAPHERS who, with the best microscopes as with a lamp, have been busy penetrating into the dark corners of nature. Such were e.g. Joblot, Hofer, Hooke, Leeuwenhoek, Grindell, Cuno, Adams, Baker, Needham, Walker, Hill, Roesel, Ledermüller, Schaefer, etc. ${ }^{90}$ Many of these, with the aid of microscopes, examined various liquors, such as wine, vinegar, infusions of pepper and of other things, and there they observed diverse bodies, swimming with a varying motion to and fro, but they did not observe whether they were true Animalcula infusoria of that kind with living bodies furnished with organs, or whether something else salty, oily etc., and they indeed did not dare to insert them into the system of animals.

\section{\$III.}

Just as the older scholastic sciences have waned especially in our age, so the practical sciences, such as Astronomy, Natural Science, Mechanics, Medicine, Chemistry, and the Manual arts, have been cultivated with greater zeal*. \{ Footnote in the original text: See the Illustrious Suhm's 'The Character of the Present Age', in Acta Societatis Nidrosiensis, Volume 3. \} Never has Economic science been propounded more solidly, in my opinion, than in the book which was anonymously produced under the name Der Hausvater, and which again appeared in two volumes in an octavo edition in Hannover in 1766. ${ }^{91}$ The inestimable author of the work is the above-lauded Freiherr Baron Otto Münchhausen, Provincial Governor and coming from the Noblest families of Hannover. This highly distinguished Man wrote to Our Lord President a decade before, that he had found that Ustilago Hordei ${ }^{92}$ consisted of living animalcules. Now at last, in the work named above, he states that

\section{p. 396}

not only is the black flour in ustilago of Barley and Wheat mere eggs; but also that the similar flour in Puff Balls, Mushrooms \& other Fungi, that the dust itself of Mucor ${ }^{93}$ is indeed nothing other than the seeds of fungi; but that these seeds, when put in tepid water for some days, germinate into real little worms, clearly visible with microscopes, and at length weave a small web, to which they stick firmly and grow into the Fungi to which they owe their origin. From there the question arises whether Fungi ought to be categorized as vegetables or indeed as animals? Or even whether a new kingdom of nature ought to be formed, which might be called neutral or chaotic. ${ }^{94}$ Should the Polypi be included here? Should living Molecules, called animalia infusoria, be included here? And this closely resembles fermentation or rotting itself. Let us transcribe the very words of the most Illustrious Author and afterwards admire the discovery itself with which the chamber, about to reveal the greatest miracles of nature, is opened to the expert priests. ${ }^{95} \mathrm{We}$ indeed regard this discovery as so great that if no 
other monuments of this highly distinguished Man existed, this alone would still furnish immortal glory to this most illustrious author. The words of the Author are:

${ }^{96}$ USTILAGO is often so abundant that it occupies a third or quarter part of the land and that all the grains are filled with a black powder instead of white flour. A more accurate examination through the microscope and experiments carried out more than one hundred times, taught me that this powder consists of nothing but small, transparent globules with small black spots inside, which are the eggs of infinitely minute insects, or rather of little worms. When these eggs are placed in a humid place and at a warm temperature, an eggshaped animalcule, which ruptures at the extremity and leaves a big quantity of eggs behind, comes out or is pushed out.

When Wheat is threshed, most grains infected with ustilago are crushed and the eggs cling

\section{p. 397}

to the bearded top of the wheat grain and so when sown, they are planted with the wheat itself. ${ }^{97}$ The animalcules which are driven out slowly move up the shoots; ${ }^{98}$ they grow with the grain stalks using the nourishment of the grain seeds planted in the soil. They consume the marrow which is still humid and finally leave eggs behind.

Therefore in order to take precautions against ustilago, it is best if the Wheat is sown when not infected by small eggs of that kind. For when there are no eggs, the animalcules can neither live nor multiply there. ${ }^{99}$ But if you cannot get hold of clean Wheat, the eggs, which are there, should at least be destroyed and should be rendered unsuitable for reproduction. If powder of this kind, which has already lasted for a year, is examined, dried out little balls can be seen inside, and so no reproduction should henceforth be feared and no other remedy is needed provided that the Wheat was dried properly and kept safe from humidity. But if the wheat needs to be planted soon, there is nothing more efficient against these animalcules, than ordinary brine, dissolved in water, by which they are immediately destroyed. Therefore grain should be moistened with lye prepared from limestone and brine. Through this method I have not seen ustilago in my wheat after twenty years, even though sometimes a third of the harvest of my neighbours was destroyed by this pest. Because I am prescribing only a basic and very simple remedy against ustilago, this will not meet the approval of most economies. Vol. 2. p. 329 where more things can be read on this matter.

${ }^{100}$ When fungi become old and especially Puff Balls and all mucor, they shed a blackish dust. If we examine this with good microscopes, little semi-transparent balls are found, full of little black dots on the inside and not different from the structure of a younger polyp. I have immersed this dust into water and placed it in a quite warm place, where the little balls immediately swelled and changed into moving egg-shaped little animalcules. These animalcules move swiftly around here and there in the water; on the second day it is observed that

\section{p. 398}

masses of a harder texture or fungi form. When the fungi begin to grow, at first veins, which are turning white, appear, which are commonly regarded as their roots: but in truth they are nothing other than channels in which the polyps move, which a little later build a big structure. If we would examine the inner substance of the fungi, especially of the dried out 
and prepared fomes, ${ }^{101}$ it appears that it only consists of the finest texture of very small elements clotted together and of complicated small channels, which were the openings of the polyps while they were alive. Space prevents us from lingering longer on these things. For me it seems indeed certain that all Corallia, Fungi, Mucores, Lichenes, Ustilagines, yes indeed almost every Fermentatio (S. 634.) ${ }^{102}$ might have their origin from polypiform creatures, which I do not yet recognize as declared animals, but which will nevertheless give me the opportunity to consider the matter further. Munckh. ${ }^{103}$

Servetus, Aquapendens and Caesalpinus ${ }^{104}$ looked closely at the circulation of blood; Harvey, ${ }^{105}$ however, who exposed this same matter to the public light, took the honour. Leeuwenhoek saw the Polypi thirty years before Trembley did, but the glory of the discovery deservedly fell to the latter who brought the nature of these same things to light. Already for a long time, very many people have seen animalia infusoria; however nobody succeeded in unravelling the mystery itself before Baron von Münchhausen.

\section{$\S I V$}

USTILAGO in Triticum, Hordeum, Scorzonera, Tragopogon pratensis and in some others, often shows a black powder with the seed matter destroyed instead of bearing fruit. ${ }^{106}$ The farmer knows that when the corn ears of this kind are crushed through threshing, the uncorrupted grain are infected by this black pollen, which then when planted, produce nothing but ears with ustilago, which increase until a great part of the corn is corrupted. Therefore the corn, destined for sowing is washed to remove the black dust,

p. 399

or even replaced with cleaner corn obtained from elsewhere. Truly this is contagion in the plant kingdom. The Author asserts that, after this dust ${ }^{107}$ is immersed into water and exposed to summer heat for a few days, real animalcules are driven from the eggs. We have seen this experiment repeated by our Lord the president when I saw with the microscope of Cuff ${ }^{108}$ many thousands of these things (otherwise invisible to the naked eye). These animalcules looked white in glass-green water, oblong, fairly blunt more to the front, swimming like playing fish, sometimes leaping; it looked as if they give way to one another, but mostly gather together in a swarm*. $\{*$ Footnote in the original text: These little worms are very similar to the vermiculi infusorii, so that I first doubted whether they were of a different species until they grew into fungi, or even mere infusorii multiplicati, since I could not continue the experiment. \} After a period of a few days, it seemed as if some were beginning to build a web at the bottom, to the anterior part of which, if I have observed correctly, they were clinging, with the rest gradually approaching to be attached to the web in a similar way, like mucor. We could not clearly see how the small worms were producing movement here; for there was no forward movement with the help of a tail like a fish, and there was no snakelike movement as in the case of Muraenae and Gordii ${ }^{109}$ and they were not propelled by an intestinal movement like the larvae of flies. However, I presume ${ }^{110}$ that there are some organs of movement under the anterior part. I could not observe any feet, but it is not a wonder, since Volvox, ${ }^{111}$ one hundred times bigger, is observed to be rotating very fast in water, with however no organs of movement visible, unless it can be concluded from the related Beroe, ${ }^{112}$ which, being one hundred times bigger than the Volvox rotator, moves with very short hairs, arranged in rows. These kinds of things would still have been obscured by much darkness if that most Famous Münchhausen had not made such good progress with his 
experiments, if he had not seen that after the black flour of the Lycoperdus ${ }^{113}$ was taken and at once immersed in lukewarm water

p. 400

and changed into an animal form, that these animalcules changed again into fungi, that is, that they lost their voluntary movement and where there was enough humid nutriment, grew into bodies with the shape of a head, ${ }^{114}$ and if he had not in this way showed us the chain leading us into the whole system of fungi. FUNGI certainly differ a lot from other plants and they have roots which are scarcely worthy of the name, since they only produce a meagre, irregular mass which only absorbs a little moisture from the damp earth. And they don't have leaves, and they don't have something similar to fruits and flowers, like mosses and ferns. Mushrooms have even dust between the lamellae, similar to the seeds of Puff Balls, which is brought to life at once in lukewarm water. Boletes ${ }^{115}$ are similar in that they have something like flour in the pores. In the case of Peziza lentifera, ${ }^{116}$ which generally lives on fences and produces big lentil-like seeds in small cups, a way could not be conceived how its heavy seeds could be transported from one place to another: ${ }^{117}$ but this enigma could perhaps be solved through these affinities which had been uncovered and through its wonderful reproduction. Natural philosophers wondered why fungi grow mostly on their own and especially in autumn, but now the reason is clear: because the seeds of these fungi require humid and tepid conditions in order to drive out the eggs; during spring and summer time, this happens with greater difficulty as a result of the wind drying out the moisture; for then the rain is absorbed quickly by the earth and evaporates on the surface: but in autumn when the air is cooling off a little, the earth, although it retains some of the heat of summer, stays humid longer after the rains, and so it is more suitable to foster the seeds. And hence it even happens that the more humid autumns produce a bigger yield of fungi than the drier ones. The illustrious Author ${ }^{118}$ even relates Mucor to this, as being very similar to fungi in its whole nature; it grows into a stalk, terminated by a small head or heads, which are ruptured or crack open into seminal dust, which is sown spontaneously and destroys the body to which it sticks.

p. 401

For we see that the smallest point of mucor multiplies itself on Lemon and consumes the whole Lemon in a short time. ${ }^{119}$ And so, what should we think about the fungi of buildings, the Byssum Septicum and Mucor Septicus, commonly known as unctuous fungi which can reduce the hardest beams of timber to dust in a short time? ${ }^{120}$ This field will certainly be wide open to exercise talents through experiments, until all these things have been explored. Erysiphe, ${ }^{121}$ which grow on plants, honeydew ${ }^{122}$ as it is usually called, with which the leaves of Maple, Hops, Galeopsis, Lithospermum tinctorium, etc. ${ }^{123}$ are stained especially in a more humid place, is without doubt a result of the mentioned cause, and seems to descend with dew because it covers the upper sides of the leaves. Because of its incomprehensible subtlety, perhaps another day will teach us how it rises into the air or evaporates from the earth like other humors.

\section{$\S \boldsymbol{V}$}

This argument will also lead doctors to the cause of exanthematic ${ }^{124}$ and contagious fevers, which they earlier found had such a great analogy with living matter, to the extent that they are warded off or attracted by cold and heat, by perfumed and smelly things, sweet and bitter 
things, and yes also by mercurials. He who has considered that only one small part of ustilago flour is multiplied through all the ears of that same Wheat or Barley plant ${ }^{125}$ will find a considerable analogy. Many have examined the pustules of Smallpox to see whether they contain any living animalcule. But it was in vain. He who has seen that the small worms of ustilago driven out in tepid water are so small that they cannot be perceived even by the sharpest eyes, will acknowledge that more exact experiments are required here, and that the pus should be dissolved in tepid water and that it should then be examined by the best microscope. At least someone with an inquisitive nature, suffering from Syphilis or gonorrhoea, should have, through experiments, searched in his foul dripping seed to see whether and what kind of animalcules it contains.

p. 402

Earlier Leeuwenhoek had discovered seminal vermiculi in all fertile seed, ${ }^{126}$ an experiment which now needs to be carried out, as it were, by other eyes; ${ }^{127}$ he said that these Little Worms were absent or found dead in syphilis patients, something which is however doubtful; ${ }^{128}$ he affirms that these (worms) become people, or that it constitutes the keel of Malpighi in the conceived egg, but this issue has not yet been clarified. ${ }^{129}$ Nobody denies these seminal corpuscles are present in the seed; whether they are indeed vermiculi of the same character as vermiculi of fungi has to be decided through experiments. It cannot be doubted that the seminal animalcules are analogous to the pollen in the anthers of flowers. ${ }^{130}$ It is further evident that the pollen of the anthers does not enter the stigma or the style, ${ }^{131}$ especially in the Mirabilis plants, ${ }^{132}$ where the pollen is almost bigger than the style and remains on top of the stigma. We see in most cases that this pollen is destroyed by contact with the moisture of the genital stigma and that it sends out a pollen tube, ${ }^{133}$ which is absorbed by the style and descends to the seed. Needham saw with the aid of microscopes that this vestige or imperceptible minute substance contained inside the pollen was expelled from the rupture of the pollen, as if out of an embolus, and that it consisted as it were of the finest spirals. Lord Turra ${ }^{134}$ made further progress, discovering that the pollen tube is absorbed by the tubular pubis of the stigma. Time will show if these are analogous to the previously mentioned.

\section{$\S \boldsymbol{V I}$}

We have seen during summer, just as Reaumurius saw, that small, as it were ethereal little clouds stayed there, of one or two ell in width, ${ }^{135}$ hovering in the air, two or three ell above the ground, quite often between the tenth and eleventh hour, especially in the month of flowering when the sun is at its brightest, and it seemed as if we have seen particles out of which this cloud consists, moving like a swarm of bees. If these would be animalcules, as we suspect not without reason, then they certainly have a similar character with those mentioned earlier.

p. 403

Some regard delicate Anguillae, ${ }^{136}$ which are observed in vinegar through microscopes, as the larvae of an infinitely small fly: which will not find acceptance, if it is true what Ledermüller says, that when dissected with scissors, these (Anguillae) are found to be filled with living offspring ${ }^{137}$ which move about actively when exposed to moisture. Moreover, these themselves, which are present in almost all gluten, ${ }^{138}$ have the characteristic that if the gluten is dried out for a whole year, they come to life again when that same gluten is 
moistened; and it seems that it does not correspond to any larva of a fly, but rather leads to this new family.

\section{$\S$ VII}

CHAOS Proteus, ${ }^{139}$ which Roesel discovered and which consists of a mucous point, invisible to the naked eye, without a fixed form but changeable into all regular and irregular shapes, angles and branches at any moment, ${ }^{*}\left\{{ }^{*}\right.$ Footnote in the original text: Roes. ins.3. $t$. 101. s. A.T. Ledermüll. micr. t. 88. s. 48 \} will also belong to this invisible world. Among Wheat Seed, imperfect kernels are often found, almost similar to half a kernel; these kernels, though they have been dried out for several years, soon after water has been poured on them, send out a corculum ${ }^{140}$ resembling a little worm. I would not dare to say whether it has animated life or not, and this will be a very worthy object of study for interested people one day.

${ }^{141}$ ANIMALCULA INFUSORIA appear in all water, especially in stagnant water or water allowed to stand for some time. Various and quite numerous numbers of these are obtained when liquids are poured on the powder of pepper and other Indian spices, according to the most common practice of Micrographers. ${ }^{142}$ But it is not really clear from where these Animalcules originate. Are they from the seeds of Mucor, disseminated into these spices, during their long preservation in closed and humid containers?

\section{p. 404}

Or were all these animalcula infusoria disseminated in ordinary water by the seed of Mucor, which fly around everywhere with the air, in the same way as in bread, meat and other food where Mucor flourishes every day?

These animals will truly one day bring the investigators of nature to the origin of the animate in animals, since it seems as if the first animated molecules are perceived here. Because Animalia Infusoria and their species have been studied more carefully now, infinite conclusions promise to be drawn about things which are still lying buried in the most dense darkness. From this we are led to consideration of the MEDULLARY substance ${ }^{143}$ of plants, whether it may become animated like that of animals, although it doesn't have nerves and cannot show clear voluntary movement, being imprisoned inside a hard cortical layer.

Meanwhile, the ORDER FUNGI now seems to be so distinct from the order of plants and the order of Zoophytes, that they are indeed at least on the border between the animal and plant kingdom, in such a way that no one could until now capture the whole sweep of nature ${ }^{144}$ to see to which of these kingdoms this province should be rightly attributed. For if seeds are changed into living animal foetuses, if these are later transformed into plant fungi, they can almost be thought of like the Progallica insects of Reaumurius ${ }^{145}$ or the Coccus of the Ilex coccifera, ${ }^{146}$ which are in the first place insects, running briskly this way and that, but the female immediately after copulation attaches itself to the cortex with its beak, located on the chest; it lives immovable and only draws nourishment through the bark with its beak; it swells day by day to the size of a pea, similar to a red berry (on account of which it was regarded by the old writers as a real berry, from which it is called the Ilex baccifera); ${ }^{147}$ inside she is full of real little eggs, which are produced inside the mother and consume her totally. In a word: just as Zoophyta flourish from a plant into small little animals, so according to an opposite law of nature, if this origin of Fungi could be confirmed, Fungi grow from Animalcules into plants. ${ }^{148}$ 


\section{$\S$ VIII}

There was a belief in Spontaneous Generation from ancient times, indeed in such a way, that it was thought that the smallest insects and larvae were generated out of decay and rottenness. For it could not be easily perceived how little worms could enter cheese or a dead body, just as Harvey could only with difficulty persuade those with sharper vision that every living thing comes from an egg, and the public even to this time are not adequately convinced by this idea. When the wondrous metamorphosis of insects was first observed - how the creeping, multi-footed, gluttonous fat caterpillar is turned into the active, fluttering, dainty butterfly - as different from its precursor as day is from night - this metamorphosis seemed more wondrous than Ovid's fictions. Once the metamorphosis of insects was understood, it was observed that the fructification and bloom of plants is nothing other than pure metamorphosis: the leaves of the artichoke are turned into the beautiful flower of the Echinopsis, Gundelia, or Morina; ${ }^{149}$ simple leaves into the loveliest Amaryllis, Gloriosa and Leonurus; ${ }^{150}$ so that it seemed as if the sanctuaries of nature themselves were being entered when uncovering this basic pattern, transformed by a kind of pre-determination. ${ }^{151}$ When Gorgoniae, Sertulariae and other Zoophytes were first observed to have Polyps, nothing could be decided for certain, until they observed that these, just like plants, were changing into animals through metamorphosis, in the same way that plants changed into flowers. And this last discovery scarcely satisfied the admiration of interested people, before another act of nature was played out here, when, with the order inverted, the metamorphosis of animals into plants took place. If these things, therefore, as our most illustrious author ${ }^{152}$ believes, lead all the way to decay and fermentation, it should be granted that amazing things are happening in the meantime in very small living molecules. It will further be a labour of many years to investigate the living seeds of all fungi and the manner of their transformation, and also the laws of generation and vegetation. When we see that the seminal little worms of Fungi

\section{p. 406}

are so delicate, that there can be thousands of them in a drop of water and that they still cannot be observed with the eye, in water earlier thought to be clean and clear, we easily notice, that in mucor itself, where the whole plant is scarcely visible without a microscope, that the seed is proportionately infinitely smaller. And so the smallest animals are so delicate that they can scarcely be imagined. ${ }^{153}$ Therefore it is no wonder that these things which are a hundred times smaller than the smallest dust particle, ${ }^{154}$ which flit around in the rays of the sun, hover in the air and are carried wherever possible and disseminate themselves everywhere. When we also observe that fungi and mould are only growing in humid places, and that mould sticks to meat, bread and to all nutriments which are moist or exposed to humid air, it is clear that these only thrive in an undisturbed and humid place. A very little piece of fungus (Mucor septicus) ${ }^{155}$ grows so fast in buildings, that the growth could almost be noticed with the eyes, and it is wholly broken up into an infinitely copious seminal powder, from which it is easily concluded that no living thing is procreated and multiplied more abundantly than these very delicate animalcules; and it is therefore no wonder that they could be sown and be present everywhere. From this incredible septic power of Mould and Fungus, we see that their seminal animalcules ${ }^{156}$ wear away any humid things they meet, just as Termites ${ }^{157}$ in the Indies; for united, their forces work stronger. 
From this we believe that infinitely many animals are not known to us, so that we could duly say with Sirach: We see only a few things of the divine works; many things bigger or smaller than these remain hidden. ${ }^{158}$ And so we must certainly speculate and investigate whether diseases, for example intermittent and exacerbating fevers, etc., ${ }^{159}$ which are prevalent during autumn, the season which is for the most part humid, tranquil and cloudy, owe their origin to infinitely small animalcules, these or closely related ones, which are contained in air of this nature. Thus a semi-tertian fever is more common in the lower and humid areas; and all

p. 407

fevers turn into Tertian Fevers ${ }^{160}$ during the warmer spring and summer, but in autumn they often cause exanthemata or petechiae, ${ }^{161}$ originating from very small animalcules of perhaps the same kind, but in greater numbers than them. But these ills, if not on an epidemic scale, are then endemic amongst almost all people living in a climate suitable to fungi and moulds of that kind, especially amongst those living in cellars; and Pthisis ${ }^{162}$ and several other diseases could be attributed to this. An estate, in which Söderberg (*) observed that scarcely any inhabitants there were living longer than ten years, but that all who moved there were immediately seized by diseases, had houses located in a low-lying and humid area, and their walls were covered at the base by fungi, mould and moss.* \{* Footnote in the original text: Söderberg in Actis Holmiensibus 1750, p. 298, publishes a very remarkable observation about a very simple dwelling of one farmer in Skalltorp, from the Dals-Ed parish, where all the people were pale, asthmatic and suffering from hectic fever, ${ }^{163}$ so that many died between 16 and 30 years; many were suffering from tuberculosis and not one healthy person was found there. And therefore servants could not be obtained, since they most certainly would have fallen ill in a short time and most of them would have succumbed. He observed that the house was situated in a valley between small mountains, and there was rock under its foundation, with the result that the water could not drain away. And then it was covered with sticky white clay, out of which the water, which was held back, immediately gave off a stinking noxious vapour. Thence there was a suffocating stench in the house; therefore the foundations and the hard floor were covered and badly infected with Flies, Moulds, Agarici and Lycoperdons. Therefore no place was better suited to chaotic worms of fungous bodies. $\}$ It seemed the best and the healthiest in any age therefore to live on high, dry, well-ventilated places; so much so, that intermittent fevers are scarcely found in some places. Hence the smallest animals perhaps cause greater destruction than the biggest; and they probably destroy even more than all the wars. But I cannot bear to proceed further with my conjectures. Another day and the diligence of a longer lifetime will bring these and more things to light. ${ }^{164}$

p. 408

\section{SCHOLIA ${ }^{165}$}

Why would Fungi appear in autumn?

Why would Mucor Septicus destroy wooden houses in certain places?

Why are Endemic Diseases more common in Autumn?

Why do those who live in the cellars of a house get more Diseases? 
Why are Shivering and Semi-tertian Fevers ${ }^{166}$ more common in spring and autumn and worse in the cellars?

Why are dwellings in well-ventilated elevated places healthier?

Does Contagion also take place in Plants and how?

Does Contagion exist in Animals in the same way?

Do Fungi belong rather to the Animal Kingdom than to the Vegetable?

Could the Metamorphosis of Fungi and Zoophytes occur in the reverse order? ${ }^{167}$

Are there still a great number of hidden Animals, which are so small that they escape our eyes?

Are Animalcula infusoria disseminated out of the Seeds of Mould? ${ }^{168}$

Should Contagious diseases be attributed to that kind of Animalcules, and exanthematic diseases as well?

Are those very small animalcules, called chaotica, merely medullary, ${ }^{169}$ and almost without an organic ${ }^{170}$ body?

Glory to God Alone

\section{Notes}

${ }^{1}$ J.C. Roos, Dissertatio academica mundum invisibilem, breviter delineatura, thesis, University of Upsala, 1767 (C. Linnaeus as praeses). C. Linnaeus, Amoenitates academicae, seu dissertationes variae physicae, medicae, botanicae antehac seorsim editae, nunc collectae et auctae cum tabulis aeneis, vol. 7, Holmiae: Laurentii Salvii, 1769, vol. 7. pp. 385-408 . Throughout we leave Latin titles uncapitalized. In the interest of brevity, we have omitted given names of authors referenced.

${ }^{2}$ O.E.A. Hjelt , 'Carl von Linnés Bedeutung als Naturforscher und Arzt', in Schilderungen herausgegeben von der Königlich Schwedischen Akademie der Wissenschaften, anlässlich der 200-jährigen Wiederkehr des Geburtstages Linné's, Jena: G. Fischer, 1909, pp. 1-66 . S. Horstadius , 'Linnaeus, animals and man', Biological Journal of the Linnean Society (1974) 6, pp. 269-275 ; G. Broberg , Homo sapiens L. Studier i Carl von Linnés naturuppfattning och människolära, Stockholm: Almquist and Wiksell, 1975 ; M. Terrall , Réaumur and the Practice of Natural History in the Eighteenth Century, Chicago: The University of Chicago Press, 2015 .

${ }^{3}$ W. Blunt, The Compleat Naturalist: A life of Linnaeus, New York: Viking Press, 1971 . N. Landell, Doctor Carl Linnaeus, Physician. London: IK Foundation, 2008.

${ }^{4}$ For a recent discussion of counterfactuals in the history of science see G. Radick , 'Presidential address: experimenting with the scientific past', BJHS (2016) 49, pp. 153-172 . 
${ }^{5}$ Available online through the library of the Hunt Institute for Botanical Documentation at www.huntbotanical.org/databases.

${ }^{6}$ W.T. Stearn, Carl Linnaeus. Species Plantarum. A Facsimile of the First Edition. Volume 1 with an Introduction by W.T. Stearn, London: The Ray Society, 1957, Chapter 7, 'The Amoenitates academicae and the authorship of the Linnaean Dissertations', pp. 51-64.

${ }^{7}$ F.J. Brand, Select Dissertations from the Amoenitates Academicae, a supplement to Mr Stillingfleets tracts relating to natural history, vol. 1, London: G. Robinson and J. Robson, 1781 . B. Stillingfleet, Miscellaneous Tracts relating to Natural History, Husbandry, and Physick. To which is added the calendar of flora, 3rd edn, London: J. Dodsley, 1775 .

${ }^{8}$ M.E. DeLacy and A.J. Cain , 'A Linnaean thesis concerning Contagium vivum: the 'Exanthemata viva' of John Nyander and its place in contemporary thought', Medical History (1995) 39, pp. 159-185 ; R. Insulander and S. Müller-Wille , 'Linnés, Fundamenta ornithologica', Svenska Linnesällskapets Årsskrift (2000-2001), pp. 85-124 .

${ }^{9}$ DeLacy and Cain, op. cit. (8).

${ }^{10}$ DeLacy and Cain, op. cit. (8).

${ }^{11}$ J.C. Roos, Dissertatio medica de lumbagine, thesis, University of Upsala, Upsala: Johan Edman, 1775 (J. Sidrén as praeses).

${ }^{12}$ S.S. Olsen , Bibliographia discipuli Linnaei: Bibliographies of the 331 Pupils of Linnaeus, Copenhagen: Bibliotheca Linnaeana Danica, 1997.

${ }^{13}$ J. Sidrén, Dissertation de materia medica in regno animali, thesis, University of Upsala, 1750 (C. Linnaeus as praeses).

${ }^{14} \mathrm{~J}$. Salberg, Dissertatio medica de cholera, thesis, University of Upsala, Upsala: Johan Edman, 1768 (J. Sidrén as praeses). E.J.M. Petersen, Morbos exanthematicos, ut effectus certarum tempestatum, thesis, University of Upsala, Upsala: Johan Edman, 1768 (J. Sidrén as praeses).

${ }^{15}$ DeLacy and Cain, op. cit. (8).

${ }^{16} \mathrm{C}$. Linnaeus, Clavis medicinae duplex, exterior and interior, Stockholm: Laurentii Salvii, 1766.

${ }^{17}$ L. Hansen, Carl Linnaeus. Clavis medicinae duplex. Two Keys of Medicine. From a Swedish translation with introduction and commentary by Birger Bergh, Gunnar Broberg, Bengt Jonsell, Bengt I. Lindskog. Translated by Peter Hogg. London: The IK Foundation, 2012 .

${ }^{18}$ Full names and dates of authors are in the footnotes for the translation. For general accounts of their discoveries see M.J. Ratcliff, The Quest for the Invisible: Microscopy in the Enlightenment, Farnham: Ashgate, 2009 ; M. Terrall , Réaumur and the Practice of Natural History in the Eighteenth Century, Chicago: The University of Chicago Press, 2015. 
${ }^{19}$ This somewhat self-congratulatory statement is misleading as the concept of zoophytes had a long prior history. C.G. Osorio , 'Sobre agentes infecciosos, zoófitos, animálculos e infusorios', Revista Chilena de Infectología (2007) 24, pp. 171-174 . In the 10th edition of the Systema naturae, Linnaeus simply raised the Zoophyta to the level of a class in the phylum Vermes. Linnaeus's persistence with the name 'Zoophyta' irritated James Edward Smith (1759-1828, his admirer and biographer, and founder of the Linnean Society), who remarked, 'Even Linnaeus ... has fallen into half-measures and ambiguities, which disgrace that part of his immortal Systema Naturae. J.E. Smith , A Selection of the Correspondence of Linnaeus and other Naturalists, from the original manuscripts, vol. 1, London: Longman, Hurst, Orme and Brown, 1821, p. 80.

${ }^{20}$ There is a biological inaccuracy here. The segments of the tapeworm do not produce more tapeworms, nor is a segment self-sustaining, but dies after disarticulating from the body of the worm.

${ }^{21}$ This is an allusion to an earlier Linnaean dissertation: H.C.D. Wilcke, Dissertatio academica de politia naturae, thesis, University of Upsala, 1760 (C. Linnaeus as praeses). For a recent analysis of early views on the role of insects in 'the economy of nature' see S.A. Wille, 'The ichneumon fly and the equilibration of British natural economies in the eighteenth century', BJHS (2015) 48, pp. 639-660 .

${ }^{22}$ Not to be confused with Hieronymus Karl Friedrich von Münchhausen (1720-1797), nor with Gerlach Adolf von Münchhausen (1688-1770); see note 89 below.

${ }^{23}$ Meaning Linnaeus himself.

${ }^{24}$ C.V. Lowther, 'Chlamydospore germination in physiologic races of Tilletia caries and Tilletia foetida', Phytopathology (1950) 40, pp. 590-603 . E. Kohler, M. Klinkowski , O. Appel and P. Soraruer, Handbuch der Pflanzenkrankheiten, Bd. III, Die pflanzlichen Parasiten, 2. Teil, Berlin: Parey, 1970 . G.W. Fischer and C.S. Holton , Biology and Control of the Smut Fungi, New York: Roland Press, 1957.

${ }^{25}$ An attempt to repeat Linnaeus's observations with what was probably the same microscope is reported in H. Nyman and L. Nilsson , 'Linnaeus and the invisible world', Zoologica Scripta (2009) 38, Suppl. 1, pp. 17-24 .

${ }^{26}$ J. Antonovics and M.E. Hood, 'Linnaeus, smut, and the germ theory of disease', manuscript to be submitted.

${ }^{27}$ T.M. Fries , 'Den Osynliga Världen. Akademisk afhandlung af Carl Linnaeus till svenska språket öfversatt', Skrifter af Carl von Linné; utgifna af Kungliga Svenska vetenskapsakademien (1906) 2, pp. 215-244 .

${ }^{28}$ Antonovics and Hood, op. cit. (26).

${ }^{29}$ This refers to the number of the dissertation in the volumes of the Amoenitates. In the Lidén numbering of the theses in the Hunt Institute for Botanical Documentation, it is number 149.

${ }^{30}$ John Ray (1627-1705). 
${ }^{31}$ 'Insects' was a term used for any small animals, even into the early $1800 \mathrm{~s}$.

${ }^{32}$ This refers to Linnaeus.

${ }^{33}$ 'Seeds of Ustilago' refers to spores of the smut fungi in the modern genera Ustilago or Tilletia, which cause smut and bunt diseases of cereals. Linnaeus claimed that these germinated to produce living animalcules. In Ustilago the spores germinate to produce a nonmotile yeast-like stage. In Tilletia the spores form balls, which, when wetted, actively extrude a filiform stage that mates pairwise to produce structures that bud off and disperse sickleshaped spores; these in turn mate and produce secondary hyphae (Lowther, op. cit. (24); Fischer and Holton, op. cit. (24)). Wheat is also infected by a seed-gall nematode, Anguina, that invades the ovary, where its progeny convert the grain into a black cyst that resembles a grain diseased by Tilletia. When this cyst is wetted, the small juvenile nematodes emerge and literally swim about with undulating motions characteristic of nematodes. This was observed and illustrated by John Turbeville Needham ( T. Needham, 'A letter from Mr. Turbervil Needham, to the President; concerning certain chalky tubulous concretions, called malm: with some microscopical observations on the farina of the red lily, and of worms discovered in smutty corn', Philosophical Transactions (1743) 42, pp. 634-641 ). The original has Turbervill Needham as author. However, in an account of Needham's discoveries ( S.A. Roe , 'John Turberville Needham and the generation of living organisms', Isis (1983) 74, pp. 158184 ), the author is not aware of this possibility and suggests that 'Needham was most likely observing the production of certain forms of water mould, species of fungus'. Therefore, because it is unclear whether Linnaeus had seen Ustilago, Tilletia or Anguina, we retain the original word Ustilago throughout the translation, and do not give it a modern scientific name.

${ }^{34}$ In the sense of 'after we were born' or as little children.

${ }^{35}$ 'Baobabs' (Bombax in the Latin original) are tropical trees in the family Bombacaceae. Bombax ceiba is the cotton tree. 'Cucumber trees' (Averhoas in the Latin original) are native to South East Asia and in the family Oxalidaeae. Averrhoa bilimbi is the cucumber tree.

${ }^{36}$ 'Others' is liberally translated from commilito, meaning 'comrade', or 'fellow soldier'.

${ }^{37}$ Johann Nathanael Lieberkühn (1711-1756 ) was a German physician whose microscopes for studying blood vessels were called 'wonder-glasses'.

${ }^{38}$ Conrad von Gesner (1516-1565), Ulisse Aldrovandi (1522-1605), Francis Willughby or Willoughby (1635-1672).

${ }^{39}$ Mathias de l'Obel (1538-1616), Rembert Dodoens (1517-1585), Charles de l'Ecluse (15261609), Jean Bauhin (1541-1613) and Caspar Bauhin (1560-1624), Joseph Pitton de Tournefort (1656-1708).

${ }^{40}$ Charles Plumier (1646-1704), Patrick Browne (1720-1790), Nikolaus Joseph Freiherr von Jacquin (1727-1817), Johannes Burman (1707-1780), Hendrik Adriaan van Rheede (16361691), Georg Eberhard Rumpf (1627-1702).

${ }^{41}$ George Edwards (1694-1773), Mathurin Jacques Brisson (1723-1806). 
${ }^{42}$ René Antoine Ferchault de Réaumur (1683-1757), August Johann Rösel von Rosenhof (1705-1759).

${ }^{43}$ Georg Eberhard Rumpf (1627-1702), Philippus Bonannus (published Recreatio mentis et oculi in observatione animalium in 1684), Martin Lister (1639-1712), Antoine-Joseph Dezallier d'Argenville (1680-1765).

${ }^{44}$ John Ellis (c.1710-1776); 'sea fir' (Sertularias in the Latin original) is a name for colonies of small marine animals (hydrozoans in the genus Sertularia) whose fern-like fronds are green because of the presence of symbiotic algae.

${ }^{45}$ This is from Greek mythology. When Theseus entered the labyrinth, he allowed the thread of Ariadne to unravel behind him, so he could to find his way back. The metaphor is used by Linnaeus in his Philosophia botanica, Aphorism \#156 ( S. Freer, Linnaeus' Philosophia Botanica, Oxford: Oxford University Press, 2003 ) to emphasize the importance of his hierarchical system (classes, orders, genera, species) as a means of quickly determining the name of a species and whether it is new or not.

${ }^{46}$ This possibly refers to so-called double flowers in which the ovary and/or stamens are replaced by petals. Such double flowers are sterile, thus showing the role of the ovary and stamens in reproduction.

${ }^{47} \mathrm{~A}$ 'prolepsis' is a verbal device that anticipates a future argument against it. Linnaeus uses this word in the sense of an anticipated or pre-formed body plan. Two Linnaean theses on plant morphology and physiology have 'prolepsis' in the title: H. Ullmark, Prolepsis plantarum, thesis, University of Upsala, 1760 (C. Linnaeus as praeses); J.J. Ferber, Disquisito de prolepsi plantarum, thesis, University of Upsala, 1763 (C. Linnaeus as praeses). The explicit idea that organisms had a body plan (or Bauplan, from the German) was put forward later by the French biologist Cuvier (1769-1832). See also P.F. Stevens and S.P. Cullen, 'Linnaeus, the cortex-medullary theory, and the key to his understanding of plant form and natural relationships', Journal of the Arnold Arboretum (1990) 7, pp. 179-220 . They interpret 'prolepsis' more in the sense of accelerated development of particular plant parts.

${ }^{48}$ Aconitum (as in the Latin original) refers to aconite or monkshood, a highly poisonous plant in the buttercup family. Extracts from it were used to alleviate the effects of the affliction known as St Anthony's fire caused by eating grain contaminated with ergot caused by the fungus Claviceps ( E. Guernsey, Homeopathic Domestic Practice, 2nd edn, New York: W. Radde, 1857 ). It seems unlikely that aconite was used on such a large scale that it 'rescued' cereal growing in Europe. In 1746-1747 there were severe outbreaks of ergotism in Sweden and Europe ( H.S. Wellcome , From Ergot to 'Ernutin': An historical sketch, London: Burroughs Wellcome, 1908 ), possibly because cold, wet summers at this time ( I. Chiune , P. Yiou, N. Viovy, B. Seguin, V. Daux and E. Ladurie, 'Grape ripening as a past climate indicator', Nature (2004) 432, p. 289 ) may have favoured this and other fungal diseases.

${ }^{49}$ Johann Jacob Dillen (1684-1747).

${ }^{50}$ Mosses and lichens were used as filling for mattresses.

${ }^{51}$ In modern parlance, the 'economy of nature' would be described as 'ecology'. In 1749 Linnaeus, through his student Biberg, wrote a dissertation, Oeconomia naturae, where the 
roles of various species in ecological cycles, food webs, etc. are outlined. For English translation see Stillingfleet, op. cit. (7), pp. 37-129.

${ }^{52}$ In the Latin original musci \& muscae, and no doubt an intended verbal juxtaposition.

${ }^{53}$ Abraham Trembley (1710-1784) demonstrated regeneration in the freshwater polyp Hydra.

${ }^{54}$ 'Of polyps' (polyporum in the Latin original) refers to organisms such as Hydra that were studied by Trembley.

${ }^{55}$ Bernard de Jussieu (1699-1777), Jean-Étienne Guettard (1715-1786).

${ }^{56}$ Henry Baker (1698-1774), Job Baster (1711-1775), August Johann Rösel von Rosenhof (1705-1759), Martin Frobenius Ledermüller (1719-1769), Jacob Christian Schäffer (17181790).

${ }^{57}$ 'Vorticellae' refers to Vorticella, a genus of stalked, bell-shaped, ciliated protozoan.

${ }^{58}$ 'Worms' (vermes in the Latin original) was used by Linnaeus for many kinds of nonarthropod invertebrate animals.

59،Gemmae' are reproductive dispersal structures produced by vegetative budding.

${ }^{60}$ This sentence appears later in the original Roos dissertation (at the end of Section IV, p. 9), but was moved to this position in the Amoenitates version, presumably by Linnaeus. It was replaced with a sentence listing the various Nautilus species (see note 82 below). Giuseppe Vianelli's work, published in 1749, on luminescent animals is mentioned by Linnaeus in a letter to Bernhard de Jussieu on 30 June 1749 (Linnaean Correspondence L1084) and became the subject of a dissertation by one of his students (C.F. Adler, Noctiluca marina, thesis, University of Upsala, Upsala: Hojer, 1752 (Praeses C. Linnaeus)).

${ }^{61}$ 'Diana's tree', also known as the philosopher's tree or arbor philosophorum, is a tree-like structure produced by adding mercury to a solution of silver nitrate. This arborescence led medieval philosophers to theorize the existence of life in the kingdom of minerals. Among alchemists, Diana symbolized silver.

${ }^{62}$ Luigi Ferdinando Marsigli (or Marsili) (1658-1730).

${ }^{63}$ Jean-André Peyssonnel (1694-1759) found that 'coral flowers' were in fact 'insects' housed within a stony structure; he was thus the first to demonstrate the animal nature of coral. (J. Vandermissen, 'Fishermen's knowledge in the academic salon: how Jean Andre Peyssonnel's studies of 'marine products' at the coasts of Barbary and Guadeloupe influenced debates on the true nature of coral in eighteenth-century Europe', Proceedings of the 5th International Conference of the European Society for the History of Science, 2012, available at http://5eshs.hpdst.gr/abstracts/243.

${ }^{64}$ Linnaeus often uses the metaphor of entering chambers or opening doors when referring to new discoveries. In the Latin original, the words patefescisset aditum evoke the same image of a hidden treasure behind a close door. 
${ }^{65}$ John Ellis, a British linen merchant and naturalist, specialized in the study of corals. J. Ellis, An Essay towards the Natural History of the Corallines, and other marine productions of the like kind, commonly found on the coasts of Great Britain and Ireland, London, 1755. He corresponded extensively with Linnaeus. For his biography see J. Groner and P.F.S. Cornelius, John Ellis, Pacific Grove, CA: Boxwood Press.

${ }^{66}$ Johann Jacob Dillen (1684-1747) was a German botanist who was appointed Sherardian Professor of Botany at Oxford. Linnaeus spent a month with him when he visited England in 1736.

${ }^{67}$ Roos's original thesis reads differently - 'Videbat haec ad singula petala seu denticulos florem ostendere animali alligato similem' - but the meaning is similar: 'He saw that these things showed a flower at the individual petals or denticles, similar to an attached animal'.

68، Zoophyta' was a name given by Linnaeus to animals he considered to have plant-like characteristics, in that they were sessile but produced Hydra-like polyps.

${ }^{69}$ Isides (= soft corals, e.g. Isis), Gorgoniae (= sea fans), Tubulariae (= tubularians and hydroids), Flustrae (= leafy bryozoans), Corallinae (= corals), Sertulariae (= bryozoans).

${ }^{70}$ 'Venus sea fan', or Gorgonia flabellum, is a colonial soft coral. Alcyonium is a genus of branched soft coral, including dead man's fingers, Alcyonium digitatum. 'Arboreo' is translated as 'branched' but these corals are often quite small. Isis hippuris is another branched species of soft coral found in the Western Pacific Ocean.

${ }^{71}$ Job Baster (1711-1775), a Dutch biologist, maintained that corals were plants, but this was hotly and successfully disputed by John Ellis. Baster had cited Linnaeus in support of this contention (Groner and Cornelius, op. cit. (65). p. 48), perhaps because in an earlier Linnaean dissertation Sertularia, a bryozoan, had been classified as a moss (R. Martin, Dissertatio botanica, qua plantae Martino-Burserianae explicantur, thesis, University of Upsala, Upsala, 1745 (C. Linnaeus as praeses)). However, by 1757, Linnaeus had realized (in another dissertation, J.H. Hager, Natura pelagi, thesis, University of Upsala, Upsala: Hojer, 1757 (C. Linnaeus as praeses)) that Sertularia had animal polyps, and Ellis was cited in support of this.

${ }^{72}$ It was generally considered that an organism was 'animal' if it moved and could react actively to the environment, whereas it was 'vegetable' or a plant if it was fixed to one spot and 'insensitive' to touch. The fact that many organisms had both features created a conundrum. To say Linnaeus settled the matter is an exaggeration. In the 10th edition of Systema naturae he simply created a name (the class Zoophyta) still implying their dual nature. That they were animals was established by Ellis, who convinced Linnaeus in correspondence that started in 1757.

${ }^{73}$ The ‘true Theory' being that zoophytes were animals.

${ }^{74}$ Tapeworms (Taenia in the Latin original) are parasites of humans and livestock, and they were the subject of an early Linnaean dissertation (G. Dubois, Specimen academicum de Taenia, thesis, University of Upsala, Upsala, 1748 (C. Linnaeus as praeses).

${ }^{75}$ Linnaeus believed that all organisms had a fundamental 'medullary' and 'cortical structure'. For a thorough analysis of this idea see Stevens and Cullen, op. cit. (47). 
${ }^{76} \mathrm{We}$ translate chylopoeis as digestive system. Chyle is an intestinal fluid.

${ }^{77}$ Triticum repens is couch grass (now named Elytrigia or Agropyron repens), a persistent weed that spreads by below-ground runners which are actually stems, not roots.

${ }^{78}$ The tapeworm does indeed have a head-like structure (termed a scolex) at the thinner end. The scolex is furnished with suckers for attachment to the intestine but it has no eyes or mouth. In the dissertation of Dubois (op. cit. (74)) on Taenia it is stated that the mouth is 'marginal, solitary'. There is a pore on each of the segments of the tapeworm, but it is a urinogenital opening; there is no true mouth, as nutrients are absorbed through the surface of the animal.

${ }^{79}$ Mushroom coral (Madrepora Fungites in the Latin original) is Fungia fungites, within the family Fungidae (no relationship to the fungi) in the class Anthozoa, to which also belong hydra and other corals.

${ }^{80}$ The body of the coral.

${ }^{81}$ 'Fire corals' are colonial marine organisms (in the genus Millepora) that are technically not corals, but related to jellyfish and other stinging anemones, hence their name.

${ }^{82}$ 'Nautilus' is the common name of pelagic marine molluscs of the cephalopod family Nautilidae. Having remained relatively unchanged for millions of years, they are often considered living fossils. Nautilidae, both extant and extinct, have shells that are generally smooth, with compressed whorls. The species of Nautilus listed here were recognized by Linnaeus in his Systema naturae, 12th edn, 1767 (p. 1162, under Vermes, Testacea, Nautilus: genus number 318), published in the same year that Roos published his dissertation. In the 10th edition, published in 1758, and certainly accessible to Roos, there is no mention of 'rugosus'. This sentence is not present in the original dissertation by Roos and replaces the sentence that was moved to p. 389 (see note 60 above). Exactly why Linnaeus thought it fit to insert this sentence in the Amoenitates version and to include the many species of Nautilus remains unclear.

${ }^{83}$ In an earlier dissertation (Wilcke, op. cit. (21)), Linnaeus considered that insects often acted as nature's police, preventing the excessive reproduction and spread of other species in order to keep the balance of nature.

${ }^{84}$ Aphis are small sap-sucking insects, also known as greenflies, in the family Aphidae, order Homoptera. 'Chermes' refers to species in the families Adelgidae and Psyllidae. 'Chermes' is derived from the Arabic word for crimson, and refers to the bright red color used for dyeing that some species exude when crushed. 'Coccus' are scale insects in the family Coccidae. 'Thrips' are tiny, slender insects with fringed wings in the order Thysanoptera. Podura is a genus of stout-bodied springtails. 'Acarus' here probably refers to mites in general. The flour mite, Acarus siro, is a pest of stored grains.

${ }^{85}$ Phalaena was a name used by Linnaeus to include most moths.

${ }^{86} \mathrm{We}$ have translated seta as hair. In botany, seta refers to the stalk supporting the capsule of a moss or liverwort, but here it probably is used to mean a hair in a general sense. 
87، Armed eyes': with a lens or microscope.

${ }^{88}$ This refers to the work of Trembley (1710-1784); see p. 390.

${ }^{89}$ Otto von Münchhausen (1716-1774). The biographers of Ellis (Groner and Cornelius, op. cit. (65)) confuse him with Hieronymus Karl Friedrich von Münchhausen (1720-1797), famous for his largely fictional stories of wartime exploits, further elaborated by Rudolf Erich Raspe (1736-1794) and subsequent writers, and after whom the medical condition Münchhausen syndrome was named. Groner and Cornelius suggest (p. 117) that the letters from Baron Münchhausen to Linnaeus were a hoax, when in fact the rich correspondence between Linnaeus and Otto von Münchhausen continued from 1751 to 1773 . A further confusion is with Gerlach Adolf von Münchhausen (1688-1770), chancellor of Gottingen ( C.T. Ambrose , 'Carolus Linnaeus (Carl von Linné), 1707-1778: the Swede who named almost everything', The Pharos (Spring 2010), pp. 5-10 ).

${ }^{90}$ Louis Joblot (1645-1723). Hofer (spelled 'Hofwer' in the original dissertation) is probably Johannes Hofer (1669-1752), who coined the term nostalgia for 'homesickness', noting its occurrence in Swiss mercenaries pining for their mountain landscapes. Robert Hooke (16351703); Antoni van Leeuwenhoek (1632-1723). We have been unable to identify Grindell; he is not in the Linnaean correspondence. The Swedish translation by Fries, op. cit. (27), also does not identify Grindell. Johann Christian Cuno (1708-1783); George Adams (17201773); John Turberville Needham (1713-1781); John Walker (1731-1803); John Hill (17161775); Jacob Christian Schäffer (1718-1790).

${ }^{91}$ O. von Münchhausen, Der Hausvater, 2nd edn, Hanover: Förster, 1766. The publication history of Der Hausvater is too complicated to explain here. The first volume appeared in 1764 (under the title Des Hausvaters) and the last and sixth in 1773. Why they were published anonymously is unclear, but their authorship seems to have been common knowledge.

${ }^{92}$ Smut of barley. However, in the letter that is alluded to (Münchhausen to Linnaeus, 9 December 1751, Linnaean Correspondence, L1351), the type of cereal on which smut occurs is not specified.

${ }^{93}$ Mucor is a bread mould, but here it may refer to filamentous fungi in general.

${ }^{94}$ Linnaeus, in the 12th edition of the Systema Naturae (1767), created the genus Chaos (class Vermes, order Zoophyta), in which he included the fungi (Chaos fungorum), the smut fungi (Chaos ustilago), and the infusoria (Chaos infusorium). Although Chaos has the classification level of a genus, numerous taxa that would have been recognized as distinct by Linnaeus are included under each of the 'species' epithets. For example, under $C$. fungorum are listed 'Lycoperdi, Agarici, Boleti, Mucoris' (puff balls, mushrooms, boletes and mucor). Under Chaos obscurae are included the fevers, syphilis, sperm, ethers and rotting ferments.

${ }^{95}$ The expert priests are those who are allowed into the chamber of mysteries.

${ }^{96}$ This section (up to note 100, page 397 ) is a Latin translation of the German from O. von Münchhausen, Der Hausvater, vol. 1, Part 1, 2nd edn, Hannover: N. Försters and Sons, 1776, pp. 149-151, paragraph 76. In Roos's dissertation this section is in smaller font, while in the Amoenitates it is in the same font as the rest of the text. 
${ }^{97}$ This is correct for stinking smut or bunt (Tilletia caries) of wheat (Lowther, op. cit. (24); Fischer and Holton, op. cit. (24)).

${ }^{98}$ In fungi, hyphae grow up the stem. In the seed gall, the nematodes are released into the soil, enter the roots of the seedling, and move to the growing tips. A.F. Bird, 'The AnguinaCorynebacterium association', in B. Zuckerman (ed.), Plant Parasitic Nematodes, vol. 3, New York: Academic Press, 1981, pp. 303-323.

${ }^{99}$ This was first shown experimentally by Tillet (1714-1791) in a dissertation which won first prize from the Academy of Sciences of Bordeaux ( M. Tillet, Dissertation sur la cause qui corrompt et noircit les grains de bled dans les épis; et sur les moyens de prevenir ces accidens, Bordeaux: Pierre Brun, 1755 , trans. H.B. Humphrey, Phytopathological Classics No. 5, Ithaca, NY: American Phytopathological Society, 1937 ).

${ }^{100}$ This paragraph is a Latin translation from O. von Münchhausen, Der Hausvater, vol 2, Part 1, 2nd edn, Hanover: N. Försters and Sons, 1766, p. 751, paragraph 758, in a section where he reviews works on fungi that are in his library.

${ }^{101}$ This may refer to a bracket fungus, Fomes fomentarius, the tinder polypore, in the family Polyporaceae.

${ }^{102}$ This refers to p. 703, paragraph 634 of Münchhausen's Der Hausvater, op. cit. (91), where Münchhausen says, 'if I am not mistaken, there is not one chemist who knows what fermentation means' (translated from the German), and then gives an example of a rather excruciating attempt by one author to define what it is. Louis Pasteur, early in his career, confirmed that fermentation was caused by living organisms, and this presaged his experiments that refuted spontaneous generation, so Münchhausen's same insight is very noteworthy.

${ }^{103}$ This abbreviation 'Munckh' for Münchhausen was not in the original dissertation, and was probably inserted by Linnaeus to emphasize that the quote is ending, especially as the format was not in smaller type, as in the original dissertation.

${ }^{104}$ Michael Servetus (Miguel Serveto Conesa) (1509 or 1511-1553); Hieronymus Fabricius ab Aquapendente or Girolamo Fabrizio (1537-1619); Andrea Cesalpino (1524 or 15251603).

${ }^{105}$ William Harvey (1578-1657).

${ }^{106}$ Triticum is wheat. Hordeum is barley. Scorzonera is a genus of flowering plants in the aster family, Asteraceae, including the edible black salsify (Scorzonera hispanica). The smut on this species is Ustilago (= Microbotryum) scorzonerae ( K. Vanky, European Smut Fungi, Stuttgart: Gustav Fischer, 1994 ). Tragopogon pratensis (goatsbeard, salsify and jack-go-tobed-at-noon) is a biennial plant in the Asteraceae, common in fields and on roadsides. The smut on this species is Ustilago (= Microbotryum) tragopogon-pratensis (Vanky, op. cit.).

${ }^{107}$ Unfortunately, we are not told from which species of diseased plant the 'dust' came. See note 33 . 
${ }^{108}$ The Cuff microscope was at that time the most advanced binocular instrument available. Its history and use by Linnaeus have been described by Nyman and Nilsson, op. cit. (25). Using the actual microscope borrowed by Linnaeus, they observed the germination of spores of Ustilago hordei, loose smut of barley, in various natural, but not sterile, water sources. They also saw 'infusorians', but did not determine the species they observed.

${ }^{109}$ Muraenae, or moray eels, are large fish in the family Muraenidae. Gordii are Gordian worms, also known as horsehair worms, in the phylum Nematomorpha. Adult worms are parasitic on insects and crustaceans. They are named after the legendary Gordian knot.

${ }^{110}$ Liberally translated from hariolor: to foretell, prophesy; to speak foolishly.

${ }^{111}$ Volvox is a colonial green alga, where several hundred cells form a hollow ball. Each cell has two flagellae, and their co-ordinated action moves the colony in a rotary fashion.

${ }^{112}$ 'Beroe' refers to comb jellies that move by plates of fused cilia (phylum Ctenophora).

${ }^{113}$ Lycoperdus refers to puffball mushrooms in the genus Lycoperdon.

${ }^{114}$ Literally 'bodies with the size of a head'. In the present context this possibly means a spore-bearing capsule or mushroom.

${ }^{115}$ Boletes (many in the genus Boletus) are mushrooms characterized by the spores being formed not on gill-like lamellae (as in the common mushroom) but in tubes under the cap; this gives the underside of the cap the appearance of being covered with pores or small holes.

${ }^{116}$ Peziza lentifera almost certainly refers to a species of bird's nest fungi, perhaps Crucibulum vulgare. Bird's nest fungi are closely related to the mushrooms (phylum Basidiomycota), and are so called because they produce egg-like, lentil-shaped structures inside cup-shaped fruiting bodies. The egg-like structures carry spores inside them that germinate to produce hyphae that penetrate rotting wood ( J. Ramsbottom , Mushrooms and Toadstools, London: Collins, 1953 ). Nowadays, the generic name Peziza is applied to the cup fungi which do not produce egg-like structures, and which are in a different phylum, the Ascomycota.

${ }^{117}$ These are spore bearing structures called 'peridioles' produced in a cup-like fruiting body, and technically not seeds. The peridioles are splash-dispersed over several feet by rain drops.

${ }^{118}$ Referring to Linnaeus.

${ }^{119}$ It is unclear which disease of lemon (Citro in the original Latin) is being referred to here; many fungal diseases of lemons destroy the whole fruit.

${ }^{120}$ These probably include, or are synonymous with, the dry-rot fungus, Merulius lacrymans. The Byssum may refer to 'thread' or 'silk', reflecting the white fungal threads (hyphae) on the surface of the wood, or the invasive strings (rhizomorphs) formed of numerous hyphae adhering side by side. 'Unctuous' (unctuoso in the Latin original) possibly refers to the superficially 'oily' nature of drops that are formed on the orange brown fruiting body of Merulius lacrymans, hence also the species name. 
${ }^{121}$ Erysiphe refers to fungal plant pathogens which cause powdery mildew.

${ }^{122}$ Ros melleus is honeydew and is formed from drops of sugary liquid discharged by aphids feeding on plants. It forms a substrate for fungal growth and quickly turns mouldy.

${ }^{123}$ Galeopsis, commonly called hemp-nettle, is a genus of annual herbaceous plants native to Europe and Asia. Lithospermum tinctorium, or dyer's alkanet, is so named because of its purple-staining roots. Its current name is Alkanna tinctoria ( C. Jarvis , Order out of Chaos: Linnean Plant Names and Their Types, London: Linnean Society of London and Natural History Museum, 2007 ; R.D. Meikle , 'Alkanna tinctoria: a nomenclatural tangle', Kew Bulletin (1980) 34, pp. 821-824).

${ }^{124}$ Diseases accompanied by skin eruption or a rash, such as measles, scarlet fever, or smallpox.

${ }^{125}$ Radicis in the Latin original is interpreted as meaning the whole plant.

${ }^{126}$ Sperm.

${ }^{127}$ Unclear if the intended meaning of 'other eyes' is other people or other microscopes.

${ }^{128}$ Syphilis can cause absence of sperm or presence of dead sperm (F.R. Sturgis, Sexual Debility in Man, New York: Paraphilias, 1900).

${ }^{129}$ Marcello Malpighi (1628-1694). The term 'keel' was used by Malpighi and others to denote the first rudiments of the spinal column in a chicken's embryo, because it is bent in the form of the keel of a ship.

${ }^{130}$ The issue of the role of pollen in fertilization remained controversial well into the early eighteenth century ( J. Farley, Gametes and Spores: Ideas about Sexual Reproduction 17501914, Baltimore: Johns Hopkins University Press, 1982 ).

${ }^{131}$ The stigma is the receptive surface of the style, which is a columnar structure connecting the stigma to the ovary.

${ }^{132}$ Mirabilis is a genus of plants in the family Nyctaginaceae known as the four o'clock plants because their flowers open late in the afternoon.

${ }^{133}$ Here we translate fovilla as 'pollen tube', but Linnaeus may have simply meant the substance contained in the pollen grains.

${ }^{134}$ Antonio Turra (1730-1796).

${ }^{135}$ An ell (Latin cognate $u \ln a$ ) is a unit of measurement, originally a cubit, approximating the length of a man's arm from the elbow to the tip of the middle finger.

${ }^{136}$ Angiuillae are roundworms or nematodes, which swim like eels.

${ }^{137}$ Many roundworms do have live births. 
${ }^{138}$ The meaning of 'gluten' here is unclear and we have left the word as such: it could mean animal glue derived from boiling animal connective tissue. It could also mean dough, or damp flour, but the Oxford English Dictionary indicates that the usage of gluten in this context did not occur till after 1800 .

${ }^{139}$ Amoeba.

${ }^{140}$ Translation of corculum is not obvious. One meaning is 'little heart', and it probably refers to larvae of insects infesting wheat grains.

${ }^{141}$ This paragraph was added by Linnaeus in the Amoenitates version.

${ }^{142}$ Microscopists.

${ }^{143}$ See note 75 above.

${ }^{144}$ We have translated geodaetes naturae as 'the whole sweep of nature' but its exact meaning is unclear. Geodetics is the surveying or the study of surface features.

${ }^{145}$ 'Progallica insects' (insecta Progallica in the Latin original) may refer to Réaumur's large work on the insects of France ( R.A.F. de Réaumur, Mémoires pour servir à l'histoire des insectes, Paris: Académie royale des sciences, 1734-1742).

${ }^{146}$ 'Ilex coccifera' refers to scale insects in the genus Kermes, in the order Hemiptera. They feed on the sap of evergreen oaks; the females produce a red dye, also called 'kermes', that is the source of red cochineal or natural crimson. The food plant of the Kermes scale insect, the kermes oak (Quercus coccifera), has holly-like leaves, hence its name Ilex, which is the modern name for the genus to which holly belongs.

${ }^{147}$ Holly also has red berries, and therefore the red berry-like females of Kermes may have been thought to be part of the plant.

${ }^{148}$ This sentence was added in the Amoenitates version.

${ }^{149}$ Echinops, or globe thistle, is a genus of flowering plants with spiny foliage in the sunflower family, Asteraceae. Gundelia is a genus of spiny, thistle-like plants also in the Asteraceae found in the Middle East. As these plants dry in the summer, they detach from the root and become tumbleweeds blown around by the wind. The original dissertation had Echinopsis seu Gundeliae; in the Amoenitates version an 's' has been substituted for 'seu'. Morina is a genus with thistle-like leaves in the Morinaceae, found in the Himalayas and Pakistan.

${ }^{150}$ Amaryllis is a small genus of flowering bulbs; the common name 'amaryllis' is now mainly used for the genus Hippeastrum, widely sold for their large lily-like flowers. 'Gloriosa', commonly known as gloriosa or flame lily, is in the family Colchicaceae. 'Leonurus', or motherwort, is a herbaceous perennial in the mint family, Lamiaceae, and formerly used as a relaxant during pregnancy and labor, hence its common name.

${ }^{151}$ This sentence has been difficult to translate as the intended meaning is unclear. Literally translated, it is 'so that it seemed that nature's sanctuary was being entered when uncovering 
this anticipated idea, transformed through a kind of pre-impregnation [or pre-payment]'. We have used the word 'basic pattern' for prolepsis (see note 47 above), and used 'predetermination' for per praenumerationem (literally 'pre-numeration'). The metaphor might be derived from entering the sanctuary of Apollo, where an advance payment or sacrifice was needed for a prophecy. In this Amoenitates version, the phrase per praenumerationem has replaced per antipraegnationem in the original dissertation, suggesting that the terminology and meaning were problematic even for Linnaeus. In modern terms, Linnaeus may be striving to say that there seems to be a 'fundamental plan' that has to be modified by a 'developmental switch' that may be 'costly' to effect. A modern biologist would be quite comfortable with the statement 'that an inborn pattern or genetic code (prolepsis) requires a particular developmental pathway or switch (praenumerationis/antipraegnationis) for its expression', even though this is almost as metaphorical as Linnaeus's version. We thank John Kuhner for discussions of this point.

${ }^{152}$ Presumably Linnaeus. This view of fermentation comes from Münchhausen (see note 102 above), who suggested that fermentation was caused by living organisms.

${ }^{153}$ Literally 'conceived of in thought'.

${ }^{154}$ The word pulvillus in the original Latin is the dimunitive of pulvinus and means 'little cushion'. We have translated it as the diminutive of pulvis (pulvisculum) meaning 'little dust particle'.

${ }^{155}$ See note 120 above.

156، 'Seminal animalcules' (seminalia animalia in Latin original) probably refers to the animals thought to be produced by the seed or spores of fungi.

${ }^{157}$ 'Termites' refers to destructive insects in the order Isoptera superficially resembling but unrelated to ants.

${ }^{158}$ This refers to the Wisdom of Sirach, and also known as The Book Ecclesiasticus or Siracides. It is a work of ethical teachings from the early second century BC written by the Jewish scribe Shimon ben Yeshua ben Eliezer ben Sira of Jerusalem. The quote is from 43:36.

${ }^{159}$ Intermittent fevers are forms of malaria caused by three different species of the malaria parasite, protozoans in the genus Plasmodium. $P$. falciparum causes fevers every other day (sub-tertian or semi-tertian) and is the most serious, $P$. vivax causes fevers every third day (tertian), while $P$. malariae causes fever every fourth day (quartan). Malaria was also known as the 'ague'. Exacerbating fevers are fevers that are continuous, often increasing, in their early stages and may include various bacterial and viral diseases, including typhoid fever caused by the bacterium Salmonella enterica, or typhus caused by bacteria in the genus Rickettsia and transmitted by lice, as well as a wide variety of viral diseases such as influenza and pneumonia.

${ }^{160}$ See previous note. 
161 'Petechiae' are red or purple spots appearing on the skin, and may have a wide variety of causes. In the past this symptom was often indicative of scarlet fever, caused by the bacterium Salmonella pyogenes (also known as Group A Streptococcus).

${ }^{162}$ Tuberculosis.

${ }^{163}$ 'Febris hectica' is hard to translate into a modern equivalent, but presumably refers to a fever where the body temperature fluctuates strongly.

${ }^{164}$ The Amoenitates version is different from the original dissertation, and was changed from 'Dies omnio venturus haec \& longe plura, quam conjectare possimus, in lucem protrahet clarissimam' to 'Dies \& longioris aevi diligentia haec \& plura in lucem protrahet'. Why is unclear, but Linnaeus may have recognized that omnio doesn't make sense, and likely should be omnis. A literal translation of the original would be, 'Every day that will come, will bring these and far more than we could guess, into the clearest light', which does not differ in meaning or intention from that in the Amoenitates version.

${ }^{165}$ Scholia are critical or explanatory comments.

${ }^{166}$ The meaning of 'shivering' fevers is unclear. See also note 163.

${ }^{167}$ The 'reverse order' would be metamorphosis of animals into plants; see pp. 404- 405, especially the last sentence on p. 404 inserted into the Amoenitates by Linnaeus.

${ }^{168}$ This question has been added into the Amoenitates version by Linnaeus. It may be the result of his correspondence with Ellis, who could find no evidence that fungal spores produced animalcules. Antonovics and Hood, op. cit. (26).

${ }^{169}$ See notes 47 and 75 .

${ }^{170}$ Perhaps meaning 'organized' or 'differentiated'. 